\title{
Glaxo goes back to basics in bid to meet new goals
}

London. The British pharmaceutical company Glaxo recently recruited Sir Mark Richmond, the former chairman of Britain's Science and Engineering Research Council (SERC) to direct its research. The appointment raised eyebrows among those who thought he would return quietly to academic life. But Richmond is quick to point out that Glaxo faces remarkably similar challenges to those he confronted at the SERC.

The company spends more than $£ 800$ million (US\$1.2 billion) a year on research and development (R\&D), more than any other British company. But like drug companies worldwide, this high level of spending on research is coming increasingly under the scrutiny of investors. Glaxo's current task is to focus its research on areas most likely to provide a basic understanding of the biological processes on which its future prosperity depends.

Richmond has joined Glaxo just as Sir Richard Sykes, the company's former research director who became chief executive officer last year, has launched a "back to basics" campaign to prepare Glaxo for the future. One of Sykes's first actions has been to reinforce Glaxo's image as a researchdriven company with a pipeline of innovative products, distancing himself from reports that the company was planning to diversify into generic and over-the-counter drugs.

At a time when patents on some of Glaxo's most profitable drugs are due to expire, Sykes sees this image as helping to inspire confidence among investors. "If we stick to what we are good at, there must be a customer base out there which is enormous and growing," says Sykes. "I firmly believe we are back on track."

Sykes' renewed emphasis on science is more than just window-dressing. He has, for example, separated management responsibility for research and for development. Some have interpreted this as a means of protecting the company's science base, given the prospect that institutional investors may seek cuts in R\&D spending. But Sykes says his goal is "to send a clear message that medical research is very critical to the future of this organization". He adds: "These activities are so different that no one person can take care of both."

Sykes also confirms his desire to incorporate recent advances in molecular and cell biology into the base of Glaxo's R\&D strat- egy. Like other pharmaceutical companies, he says that Glaxo is less interested in the immediate gains to be made from recombinant drugs than in developing an understanding of the biological basis of chronic diseases that will lead to new therapeutics in the long term. "We are not putting a "for sale' notice over our chemistry departments," says Richmond. "But there is a clear shift in balance between chemistry and biology."

Some critics claim that Glaxo is moving too slowly in this direction. Frustration with the company's cautious approach to radical new genome-based ventures was one reason why its director of biotechnology, Tim Harris, recently left to join Sequana Therapeutics, a small US gene therapy company based in California.

Sykes argues that, at least in the foreseeable future, gene therapy will have limited applications and markets, and that developing therapeutics for the more common chronic diseases will demand a better understanding of the complex genetic and environmental factors involved. "We don't wish to become a major gene therapy company at this stage," says Sykes. "We need to be involved, but also to ensure that we do not run off at a tangent," says Sykes.

But he also accepts that Glaxo was relatively slow to take up genetic engineering; it eventually had to buy the Swiss operations of the US biotechnology company Biogen as its entry ticket. With this in mind, the company now seeks strategic alliances with small drug development companies to keep abreast of various leading-edge innovations.

Similarly, Glaxo is turning more than in the past to university groups to keep up with relevant fundamental research. The pharmaceutical industry is now "much more openly interactive [with the basic research community]", he says.

Richmond, is likely to play a central role in steering Glaxo's interests through the thorny political debates over the extent to which the biomedical research community should be harnessed to the goals of the pharmaceutical industry.

Sykes, for example, believes that British charitable trusts need to be more commercially minded about exploiting research they fund, arguing that many British charities "have no clear mechanism for dealing with their results".

As a member of the government's new Council for Science and Technology, Sykes is well placed to ensure that his views are closely listened to in Whitehall. As chief executive of one of Britain's most researchoriented companies, his success in putting the government's ideas into practice will be closely watched.

\section{Weak evidence for human link to BSE infected meat}

London. Despite scientists' calls for caution, Britain's media last week gave extensive coverage to a 16-year-old girl thought to be suffering from Creutzfeld-Jakob disease (CJD), the human equivalent of bovine spongiform encephalopathy (BSE).

Speculation that the girl might have contracted the disease through eating infected meat - in particular hamburgers - was not dampened by the fact that all attempts to find evidence that the disease can be transferred to humans in this way have drawn a blank.

Of the 50 new cases of CJD reported each year in the United Kingdom, about 15 per cent are thought to be result from inherited mutations in the gene implicated in CJD. Most of the remaining cases have no known cause, and are termed "sporadic". The 16year-old girl, Vicky Rimmer, is thought to be such a case, although at present doctors say that CJD is only a "possible" diagnosis.

Richard Lacey, a microbiologist at Leeds University, says he is "certain" of the link between BSE and CJD in Rimmer's case, citing various "significant" factors such as the fact that 16 is a very young age to contract the disease.

But there have been at least two reported cases of CJD in teenagers, one aged 16 and the other 19. Both were sporadic cases, and are described by Robert Will, head of the CJD Surveillance Unit at Edinburgh, as "absolutely exceptional".

Other evidence used by Lacey to back his claim that BSE can be transmitted to humans is the doubling of known cases of CJD since the start of the current scare and two reported cases of farmers who had been in contact with BSE-infected cattle. The first case was published in The Lancet in 1992, and the second came to light last year.

"When we identified the second farmer, we felt it was something we had to investigate," says Will. Through European colleagues working on similar studies, he found one case of CJD in Belgium in 1991, two in France in 1992 and three in 1993.

But Belgium has never had BSE, and the few cases of BSE in France occurred in very different regions of the country from the instances of CJD. Will says this may show a link between farming and CJD - but nothing else.

Many scientists now fear that, as new research is published, newspapers will jump on unexpected results and publish alarmist reports. "The media are entitled to write what they want; I am a great believer in the freedom of the press," says Will. "But it is often forgotten that alarmist reports can cause a great deal of distress. Even so, we are determined to ensure that everything we find is put in the public domain." Fiona Gammie 